\author{
Martin Hellwig \\ University of Mannheim
}

\title{
On the Economics and Politics of Corporate Finance and Corporate Control ${ }^{0}$
}

\section{Introduction}

The purpose of this paper is to call for a reassessment of the significance of corporate finance for corporate control and for a reorientation of the theory of corporate governance. The long-running repertory play "Banks versus Markets" should be taken off the playbill for a while, to be replaced perhaps by a new offering "Career Patterns, Intrigues, and Resource Allocation in Insider Systems with Mutual Interdependence".

According to the recent authoritative survey by Shleifer and Vishny (1997), "corporate governance deals with the ways in which suppliers of finance to corporations assure themselves of getting a return on their investment." Through suitable governance mechanisms, "advanced countries... have assured the flow of enormous amounts of capital to firms, and actual repatriation of profits to the providers of finance." This view rests on the notions that (i) the corporate sector needs external funds for investment, (ii) the financial system channels such funds to the corporate sector from the household sector, and (iii) in this system the interests of external providers of funds are safeguarded through control rights giving them scope for interfering with management misbehaviour.

With this view of corporate governance, the literature has studied the incentive implications of different governance mechanisms for company management and financiers. Attention has focussed in particular on the free-rider problem that arises if a company has many outside financiers and the resources that any one of them devotes to monitoring and controlling the company's management provides benefits to all of them jointly. This free-rider problem is seen as being reduced if finance as well as control are somewhat concentrated - as in the case of a company having a large shareholder (Shleifer and Vishny (1986), Admati et al. (1994)) or a company having an exclusionary "main-bank" 
relation (Diamond (1984), Mayer (1988), Hellwig (1991)). A similar albeit temporary concentration of finance and control is seen at work in disciplinary hostile takeovers (Manne (1965), Grossman and Hart (1980), Jensen and Ruback (1983)). ${ }^{1}$ The different mechanisms have different allocative implications, so a large research program proposes to develop comparative welfare assessments of the different mechanisms by working out the details of their allocative implications; for an example see the recent comparison by Bolton and von Thadden (1998) of outside finance with a large shareholder and dispersed outside finance through an organized market with a takeover mechanism.

Methodologically this theory of corporate governance can be seen as a branch of applied contract theory. A typical study proceeds by describing a set of interrelated incentive problems, then considering the allocative implications of different contractual arrangements, and finally suggesting that prior negotiations will induce the different parties to choose an arrangement that is incentiveefficient, i.e., Pareto-efficient under the various relevant incentive compatibility constraints. This line of analysis is common to both, the "complete-contracts" approach of the early literature, e.g., Jensen and Meckling (1976), Grossman and Hart (1980), Diamond (1984), and the "incomplete-contracts" approach of the more recent literature, e.g., Aghion and Bolton (1992), Dewatripont and Tirole (1994), Hart (1995), see also the systematic treatment in Tirole (1998). Analyses using an "incompletecontracts" approach typically allow for endogenous role assignments and/or the possibility of subsequent renegotiation of contracts, but otherwise they resemble the "complete-contracts" approach in starting from given game forms and assuming that contracts inducing incentive-efficient outcomes in these game forms provide the clue to understanding institutional arrangements in the real world. In both approaches, initial contracts, in combination with the participants' expectations about their implications for subsequent events, play the role of a constitution which governs all that happens in the course of the relationship that is analysed.

I do not want to question the importance of the insights that this literature has yielded. I would however like to suggest that there are some important phenomena which it fails to capture. As an example, consider the evolution of shareholders and shareholder rights at Union Bank of Switzerland (UBS) since the seventies. In 1975, UBS introduced the instrument of name shares with a right for management to disapprove any transfer of title in these shares without giving reasons. Ostensibly this was done to demonstrate to the authorities the "Swiss" character of the bank, but in fact the right to 
refuse somebody as a new name shareholder applied to anybody, regardless of nationality. Bearer shares were maintained as a means of retaining shareholders from abroad, but relative to its nominal value and its dividend rights a bearer share had only one fifth of the voting power of a name share; moreover aggregate voting rights of bearer shares were kept below $50 \%$, safeguarding a majority for name share holders. A decade and a half later corporate managers in Switzerland found that management discretion over the registration of name shareholders created adverse political reactions in Switzerland and abroad; so, after Nestlé had taken the lead, in 1990 UBS abolished this regulation, but at the same time it instituted a 5\% rule: No one shareholder and no group of shareholders acting in concert may vote more than $5 \%$ of the votes of outstanding shares at a shareholders' meeting. In the context of a subsequent shareholders' meeting the President of the Administration Council actually suggested that commonness of opposition to management proposals was evidence of concerted voting and hence reason to invoke the $5 \%$ limit. In the mean time, in the early nineties another bank trying to play the role of the large shareholder of our governance theories had assembled a significant block of name shares, estimated at some $18 \%$ of overall votes. When this bank claimed a say on UBS policies, in 1994 UBS management discovered that the preferential voting-rights of name shares were fundamentally unfair to the holders of bearer shares and got a shareholders' meeting to abolish this "discrimination". ${ }^{2}$

Each change of rules anew was approved by the requisite two-thirds majority of shareholders represented. However significant portions of votes were not cast by shareholders in person, but by banks representing them. These proxy votes were subject to a legal stipulation that the banks casting them had to vote for the proposals of management unless the shareholders in question had given explicit instructions to the contrary. The 1994 vote on the abolition of voting-rights privileges for name shares also involved a large block of name shares from UBS's own portfolio being voted by a private individual to whom UBS had "sold" this block, while using a simultaneous forward "repurchase" to insulate this person from whatever losses the elimination of voting-rights premia from name share prices might entail. 
Generalizing from the example, I draw three main conclusions:

- The "charter" of an institution with a certain length of life should be interpreted as the result of the institution's history rather than prior contracting. As such it will be shaped by interim strategic considerations rather than an ex-ante concern for incentive efficiency.

- Whatever control rights assignments the charter may stipulate, management must be expected to actively try to immunize itself against control from outsiders. To the extent that it succeeds, this serves to neutralize governance mechanisms based on active outsider involvement.

- The notion of a given game form representing a given set of interrelated incentive problems does not capture the essence of the strategic situation. Management's ability to invent new moves and new rules may be an essential element of the overall relation between a company and its outside shareholders.

An analogy from "incomplete-contracts" theory may be helpful. Grossman and Hart (1986) introduced the notion of "incomplete contracting" in order to understand the significance of "ownership". In their interpretation, "ownership" represents a "residual control right", i.e., the right to dispose of the object in question in all those circumstances for which no other control rights assignment has been specified. In the actual modelling, the word "residual" loses some of its meaning because in fact the contract that is described specifies control rights assignments for all circumstances that can arise within the model. Even so, the notion of "residualness" is regarded as an important theoretical innovation in their work.

The above account of governance at UBS over the past twenty-five years suggests that perhaps one should apply the notion of "residualness" to management's power to disenfranchise outside shareholders, i.e., assume, without bothering to specify any particular game form, that in all circumstances not otherwise provided for, management has the effective power to set the rules of decision making so as to immunize itself against unwanted interference from outsiders. Proceeding further from the example, in this paper I shall argue that such a residual power of management to disenfranchise outsiders is to be found in many systems; significant elements of it are to be found 
even in the United States, according to LaPorta et al. (1998) the country with the strongest "antidirector rights" of shareholders.

Given this observation, the paper will explore the functioning of a system in which the residual power of corporate management to immunize itself against interference from outsiders is virtually unchecked. I shall argue that, contrary to what the initial quotation from Shleifer and Vishny (1997) might lead one to expect, such a system is not necessarily hampered by a scarcity of funds in the corporate sector. It may however be affected by a misallocation of funds in that some firms may have inefficiently low investments while others may be wasting "free cash flow". In such an economy the task of the financial system may not be the traditional one of channelling funds from households to firms, but rather to channel funds from firms with excessive cash flow to firms with insufficient cash flow.

Politics is an important part of the system. In the UBS example a major role was played by the law requiring banks to cast their clients' proxy votes on the side of management unless the clients give orders to the contrary. By such a law, the political establishment aligns itself with incumbent management; such an alignment is to be found in many countries. It is therefore important to understand why this takes place, what are its implications for the functioning of the political system, and what are its implications for the allocation of resources; presumably the support of incumbent corporate management by the political system is not altogether gratuitous.

In the remainder of the paper, in Section 2, I shall first discuss in detail why I consider traditional notions of control of firms by the financial system to be exaggerated. Thereafter, in Section 3, I shall discuss the allocative implications of the analysis. Finally, in Section 4 , I shall consider the political economy of corporate finance and corporate control.

As may be apparent from the UBS example, much of the argument is developed from the perspective of continental Europe. One may therefore wonder to what extent it can be applied to, e.g., the United States. Shouldn't one be looking at differences between continental Europe and the United States so as to get some understanding of the relative performance of different systems? This has been the standard research strategy of comparative institutional analysis in finance, from the discussions of the 
"main bank relation" by Gerschenkron (1962) or Mayer $(1988,1990)$ to the more recent systematic accounts by La Porta et al. (1997, 1998, 1999a, 1999b) of "law and finance" in different countries.

To some extent I shall pursue the opposite strategy, dwelling on similarities rather than differences, or, more precisely, similarities behind apparent differences. I shall argue that seemingly different institutional arrangements in different countries may serve similar functions, catering to similar interests. For instance, a poison pill provision in the charter of a US company incorporated in the State of Delaware serves the same purpose as the provision in charters of Swiss companies that give management the right to refuse the registration of a new holder of a name share. A comparative institutional analysis that takes observed differences at face value may miss these functional similarities and overlook the universality of, e.g., a phenomenon like management working to emancipate itself from the control of its financiers. Institutions and regulations may be different in different countries with political and legal environments, but some of the differences may be apparent rather than real in the sense that a given purpose of a given interest group may be achieved by different means in different environments.

I do not actually want to suggest that governance systems in different countries are all the same. However it is sometimes quite difficult to pinpoint precisely what the differences are and why they are there. Underlying this difficulty is an identification problem.Whereas the traditional comparative approach takes institutions and regulations as given and studies their impact on behaviour and performance, institutions and regulations are not in fact exogenous. At least in part they reflect the pressures of organized interests, including the interests of corporate management and the financial sector, on political and judicial decision making. To the extent that they do, a comparative approach that considers only the one-way causality of the effects of institutions and regulations on corporate control and corporate finance is subject to simultaneity bias. To understand the differences in corporate governance across countries, one has to look at differences in regulations and in the reality of governance jointly as the result of more fundamental differences in social, political, and legal traditions. For this purpose it is important to take account of the political economy of corporate governance and to appreciate the mechanisms affecting the evolution of institutions and regulations as well as the mechanisms linking regulations to finance and governance. 


\section{Corporate Finance and Corporate Control}

\subsection{Do Firms Trade Control For Finance?}

The notion that outside financiers exert control over firms rest on the hypothesis that firms are systematically willing to trade power of control for finance. This notion is problematic. It overlooks the fact that (i) even in advanced economies a significant portion of investment is financed from retained earnings, (ii) investment and financing strategies are frequently chosen with a view to preserving the independence of incumbent control, and (iii) even in cases where previous contracts have provided control rights to outside financiers, subsequent developments may provide management with an opportunity to void these contracts.

The importance of retained earnings corresponds to the "pecking order" discussed by Myers and Majluf (1984): New investments are financed first by retained earnings, then by loans, and only in the last instance by new share issues. Some firms will restrict their investments to what they can finance by retained earnings; others will restrict them to what they can finance by retained earnings and loans. Few firms look at the stock market as a regular source of new funds. ${ }^{3}$ Indeed for publicly listed firms in the United States, Rajan and Zingales (1998) show that the stock market plays a role for external finance at and shortly after the initial public offering, but not thereafter; for mature firms the financing contribution of the stock market is negative as shares are repurchased, e.g., in the context of leveraged buyouts. Interestingly, for mature firms, the financing contribution of loan finance is also negative as loan renewals fall short of loan repayments.

Myers and Majluf relate the "pecking order" of finance to differential costs of adverse selection in a model in which management has private information about investment prospects. A simpler explanation may be based on differential implications of the different sources of finance for control: Reinvestments of retained earnings are effectively decided upon by management acting 
autonomously. Even if the approval of a shareholders' meeting is needed, this is taken for granted in a world in which shareholders find it difficult and expensive to organize an opposition against management. In contrast, investments financed by loans require the approval of the lender who has to put up the money; moreover they entail a risk that if things turn out badly one may become dependent upon the lender's good will to continue the enterprise. Finally, new share finance requires the surrender of further voting rights to outsiders, which may enhance the risk of a loss of control by incumbent management or incumbent block shareholders.

In a recent survey of small and medium size privately held German companies, Harhoff (1998) asked - inter alia, see also Harhoff and Körting (1998) - whether respondents would have profitable investment projects to pursue if they had a profit windfall amounting to about $10 \%$ of the preceding year's sales. Out of 1509 respondents, 819 answered affirmatively. A follow-up question asked whether they would also pursue these investment projects if at current market rates they were offered additional loans of comparable size. More than one half of those who had answered affirmatively to the first question now answered no! Only 334 respondents answered yes. The same pair of questions referring to innovation projects yielded 564 affirmative responses if funds were available from windfall profits and 220 if funds were available from additional loans. These response patterns correspond to the findings of earlier surveys by Fischer (1990), Edwards and Fischer (1994), and Gerke et al. (1995), in which respondents consistently expressed an aversion to external finance based on a fear of losing control of their companies.

At the level of share finance, the fear of losing control is a major reason for the fragmentation of share classes that has been prevalent in continental Europe until very recently. Non-voting shares, bearer shares with reduced voting rights, name shares with restricted transferrability - all these are tools by which incumbent entrepreneurs/managers try to retain control over the majority at the shareholders' meeting. Retentions of large blocks serve the same purpose; they too enable incumbent insiders to retain control. This device is most effective when combined with a hierarchical company structure: Even a large industrial compound can be controlled with a relatively small investment if the insider has a controlling stake, say $50 \%$, in one company, which in turn has a $50 \%$ share in another company, etc.; the significance of such arrangements is discussed by Barca (1995) 
for the case of Italy, by Franks and Mayer $(1995,1998)$ as well as Becht and Böhmer (1997) for the case of Germany. ${ }^{4}$

The importance of concentrated shareholdings that La Porta et al.(1998, 1999a) observe in many countries may reflect such holdings by insiders rather than the kind of solution to the free-rider problem that is studied in the literature on large shareholders as monitors and controllers of corporate management (see, e.g., Shleifer and Vishny (1986), Admati et al. (1994), Bolton and von Thadden (1998)). Even where we do observe a separation of concentrated shareholdings and management, this may be the result of generation change and inheritance arrangements rather than any exchange of control for finance. In the second or third generation, the heirs of the founder may not want to or may not be able to run the company on a day-to-day basis. At the same time they may not want to sell it, e.g., because the market for companies is impaired by lemons considerations and they expect to get significantly less than the company's value. Then they need to hire a manager to run the company. The ultimate control right, namely the right to fire the manager, does not actually change hands in this transaction.

Relations between the controlling family and the manager in this setting will have some of the features of an agency relation, but this does not imply that the block holders who monitor and control the manager will do so on behalf of all shareholders. To the extent that there are conflicts of interest between them and the outside shareholders, they will want the manager to act as their agent and to defend their position against the outsiders. In particular, they will want him to maintain the value of their controlling position, avoiding any possibility of dilution of their power by the outsiders. Depending on how effective they are at controlling him, the manager may follow suit, or he may try to become more independent by playing the different classes of shareholders off against each other, transforming the blockholders themselves into "outsiders" (along with the other outsiders). In the final analysis, such power struggles may have more to do with dynastic infighting in a feudal system than with the notion of a systematic exchange of control for finance and the exertion of control by outside financiers. 


\subsection{Do Firms Surrender Control To Banks To Get Loans?}

Entrepreneurs' fears of losing control concern loan finance as well as share finance. For the case of Germany in the nineteen-eighties, this is amply laid out in Fischer (1990) or Edwards and Fischer (1994). According to their findings, based on interviews with a small sample of firms and banks, firms - almost regardless of size - tried very consciously to avoid borrowing strategies that would put the banks into the driver's seat. Moreover they went out of their way to cultivate multiple banking relations in order to avoid dependence on any one bank. While one of the banks might be designated "the main bank" (Hausbank), according to Edwards and Fischer, this designation would not provide the bank with significant power. For instance, loan rates were by and large the same for "main banks" and other banks, reflecting the firms playing the different banks off against each other in loan negotiations. Deviations from this pattern tended to involve firms in difficulties that managed to exploit the fact that "their banks" were committed to them, having been unable to withdraw in time. In these instances, the very prominence of the "main bank" position was problematic for the bank as it was subject to public pressure to keep the firms alive or else suffer the costs in terms of publicity and/or relations with political authorities.

How representative is this picture? The more recent study by Harhof and Körting (1998), based on a more extensive survey of some fifteen hundred small and medium-sized firms, finds the same multiplicity of banking relations of firms; in contrast to Edwards and Fischer, they find that even with this multiplicity, there is significant concentration in loan provision. However, this concentration in Ioan provision seems to have no impact on the availability of funds or on the terms at which the money is lent. If there is any effect at all, a firm with a long and favourable credit history with "its main bank" may face a lower collateral requirement. The same conclusion is drawn by Machauer and Weber (1998) from their study of bank lending based on internal bank data from recent years.

The use of collateral provides a key for understanding bank lending to firms in Germany. In assessing the quality of bank lending decisions in Germany, Edwards and Fischer (1994) suggest that (i) "main banks" do not in general have a significant information advantage over other banks, at least not one that is reflected in firm behaviour, firm performance, or even the bank's ability to foresee oncoming difficulties, and (ii) most bank lending in Germany is protected by wholesale collateralization, which 
implies that for the banks at least even bankruptcy is not an unmitigated desaster. According to the systematic study of Gessner et al. (1978), German banks collect an average of some $80 \%$ of their claims on collateralized loans in bankruptcy; this contrasts with $60 \%$ for suppliers' claims protected by reservation-of-title clauses and $3 \%$ for unprotected claims. Given such protection through collateralization, the banks do not an incentive to spend many resources on monitoring and can perhaps do without much control over their borrowers' activities. More generally, the explicit specification of debtor obligations under loan finance may provide for financing relations in which control by the financiers plays only a subordinated role.

This picture is rather at odds with the myth of the German "main bank system" as articulated initially (?) by Jeidels (1905) and Riesser (1910) and taken up later, e.g., by Gerschenkron (1962) and Mayer (1988). According to this myth, a firm in need of external funds obtains loan finance by committing itself to one bank, the "main bank", providing this bank with a position of exclusivity which would enable it to control the firm and thereby assure itself of a return on its investment. For the overall allocation of resources, such a "main-bank relation" is said to be advantageous because it encourages the funding of projects with long gestation periods that might otherwise involve all sorts of abuse and suspicion in the interim (Mayer (1988), von Thadden (1995)). The "main bank relation" is also seen as encouraging funding in situations involving inital uncertainty about firm quality: As the exclusivity of the relation prevents the borrower from going elsewhere if things turns out well, it enables the lender to share in the long-term rents from those initial financings that happen to be successful and therefore makes him more willing to accept the initial quality uncertainty (Mayer (1988), Fischer (1990), Sharpe (1990)).

Note however that Gerschenkron (1962), perhaps the most effective propagator ${ }^{5}$ of the myth of the "main-bank system", treated the use of banks to finance German industrialization as a sign of "economic backwardness". The 'normal' source of funds in an advanced economy was taken to be internal finance. Indeed, this had been the main source of funds for fixed capital investment in the Industrial Revolution in England, some coming from "initial" wealth, family, and personal friends, most however from retained earnings. This was feasible because initial outlays required to achieve an efficient scale, e.g., in textile production, were not all that large (Landes (1969), Mathias (1969), Crouzet (1972)). A century later an efficient scale of investment in steel, power production, and 
chemicals, then the advanced sectors, transcended the means of an individual with family and friends and required either accumulated funds from earlier industrial activities or in the "backward economy", where such accumulated funds were unavailable, the mobilization of external finance through banks or the government (the latter in Russia in the eighteen-nienties). As he was sketching the role of the "main bank" controlling a firm and relying on this control to assure itself of a return on its investment, Gerschenkron emphasized that he considered this to be a transitory phenomenon, which was bound to disappear as the "backwardness" of the economy receded and firms had retained earnings on which to rely for further finance.

Aficionados of the repertory play "Banks versus Markets" have tended to cite Gerschenkron for his account of the "main-bank system" and to ignore his account of the tendency of firms to emancipate themselves from the dependence on external finance and on banks. Gerschenkron himself substantiates this account by an assessment of bank-firm relations in the German chemical industry after the turn of the century. Already the contemporary authors had observed that, following the crisis of 1903/04, the character of the "main bank relation" was changing (Jeidels (1905), Riesser (1910)). Modern historical research shares this assessment of bank-firm relations after 1900 (see, e.g., Edwards and Ogilvie (1996), Feldenkirchen (1979), Fohlin (1998b), Pohl (1983)). Some authors even question whether in its putative heyday between the 1870's and the turn of the century, the "mainbank system" represented the "ideal type" of bank-firm relations in Germany. ${ }^{6}$ For the nineteentwenties, the recent study by Wixforth (1995) shows that even the steel industry had almost entirely rid itself of any controlling influence of banks.

As discussed in Hellwig (1991), such developments raise questions about the stability of governance systems based on exclusionary relations tying firms to their "main banks". Whereas Mayer (1988) and apparently also Shleifer and Vishny (1997) regard the "main bank relation" with significant power on the side of the bank as an internally stable system of governance, it seems that in fact this system is subject to erosion by firms desiring to emancipate themselves. Such emancipation is possible if retentions suffice to finance investments; it is also possible if accumulated retentions provide the firm with enough of a capital base for them to be able to play different banks off against each other in loan negotiations. Lending to large - and sometimes even to medium - sized - companies in Germany is viewed as being extremely competitive (Edwards and Fischer (1994)). 
So far in this discussion I have not considered the role of banks holding blocks of shares in their own portfolios, bank representatives sitting on company boards or banks voting at shareholder meetings as proxies for their clients. All these figure prominently in the myth of the German "main bank system" (Jeidels (1905), Riesser (1910), Gerschenkron (1962)), but their significance is far from clear. Somewhat contrary to the myth, Fohlin (1996) shows that these roles of banks only emerged in the second half of the eighteen-nineties, "well after the period considered pivotal for the development of heavy industry and after many firms had achieved financial self-sufficiency". Noting that the rise of interlocking directorates involved firm representation on supervisory boards of banks as well as bank representation on supervisory boards of firms, she accounts for the phenomenon in terms of networking effects rather than bank control over firms.

A similar interpretation is given by Ziegler (1998), who finds that in a sample of 78 German companies in 1927/28, 14 had no bankers, 12 had exactly one banker and 52 had two or more bankers (from different institutions) on their supervisory boards. In his view, the multiplicity of banks represented on supervisory boards of industrial companies indicates the extent of competition between them rather than any significant power of control. Indeed the individual top banker sitting on twenty of more supervisory boards simultaneously would have found it difficult to have more than a distant involvement with any one of the companies in question. I shall return to this issue in Section 4.2 below. For the moment I merely note that bank representation on supervisory boards of firms does not seem to be closely related to bank finance of firms, let alone a surrender of control by firms to their banks in return for finance.

\subsection{Are Promises of Control for Finance Credible?}

To the extent that bank finance does involve an element of control by the "main bank", this tends to be a matter of implicit rather than explicit contracting. For instance, the exclusivity of a "main bank“ relation can hardly be stipulated explicitly in a contract; a contractual clause restricting the firm to just its "main bank" would most likely not be enforceable in court. Exclusivity may however be the result of an implicit understanding, supported by (i) a threat of the bank to call in loans at short notice if the 
firm were to misbehave and (ii) a reluctance of other banks to step in as the information advantage of the "main bank" makes them fear the possibility that the client comes to them only because the "main bank" has decided to throw him off as a bad risk (Fischer (1990), Sharpe (1990)). The power of the „main bank“ then depends on the effectiveness of this mechanism.

However, the more effective the threats of the "main bank" are, the greater is the incentive for the firm to try to get out of the bank's hold. As discussed in Hellwig (1991), Rajan (1992), and von Thadden (1992), any device that strengthens the position of the bank over the firm will also raise the prospect of power abuse. This provides incentives for the firm to try to escape, e.g., by developing alternatives, if necessary in secret. On this point, Fischer (1990) gives the example of a medium-size company that started out with an exclusive main-bank relation and at some point went out of its way to cultivate "information relations“ with a second bank, even without obtaining much finance from them. When some two years later the main bank tried to renegotiate its loans terms, the firm was very happy to have the second bank as an alternative, available because the intervening „information relations“ had reduced their fear of a winner's curse problem.

If we start from the view of Gerschenkron (1962) or Mayer (1988) that exclusivity in bank finance may be advantageous because the power given the bank in an exclusive relation may be needed for the firm to obtain its initial funds at all, the behaviour of the firm in Fischer's example amounts to a «breach » of the initial contract. However regardless of what the initial contract actually was in this particular case, it seems clear that such a „breach“ can hardly be prevented if the firm's management sets its mind to it.

To assess this issue further it will be interesting to see how bank-firm relations in Japan will continue to evolve. For the post-war period, Japan, even more than Germany let alone any other country of continental Europe, has been regarded as the epitome of a system built on „the main-bank relation“ (Mayer (1988), Hoshi et al. (1991)), in which banks relied on their power over firms to collect rents (Weinstein and Yafeh (1998)). Even in Japan though some emancipation of firms from banks seems to have taken place, relying on newly developed bond markets as well as internal finance as alternatives to bank finance (Hoshi et al. (1990)). The effects of the ongoing recession-cum-banking crisis remain to be seen. 
The notion that management has a tendency to rescind control rights and control powers of financiers applies to outside shares as well as to bank debt. With share finance, the problem of viability of promises of control arises in yet another way. In contrast to the creditor, the shareholder does not have an well-specified financial claim on the company. He only has the right to participate in future shareholder decision making concerning the distribution or retention of earnings or the election of certain officers of the company. Whereas the exclusivity of a "main-bank“ relation provides the bank with an implicit provision of control, the outside shareholder is actually given an explicit control right in return for the finance he provides. However with dispersed share holdings, exertion of this control right is hampered by free-rider problems (see, e.g., Grossman and Hart (1980)). In the usual process of affairs, management can therefore expect to proceed without interference from outside shareholders unless their " voice » is organized either through a third party collecting proxy votes or through the concentration of a large block of shares with a single party, in the most extreme case a hostile takeover.

Given this state of affairs, the management of a company with dispersed outside shareholders has a significant incentive to make sure that shareholders remain dispersed, i.e., that there be no hostile takeover and no other concentration of a controlling block of shares outside of their own control. To the extent that this is legally permitted, incumbent management will therefore try to use its incumbency, including its power to manipulate or otherwise influence the shareholders' meeting, so as to make sure that the control rights associated with shares remain dispersed and therefore ineffective. The UBS case that I summarized in the introduction provides a rather striking instance of this.

Altogether the state of relations between dispersed shareholders and the company is very well characterized by the bonmot of the German banker Carl Fürstenberg (1850-1933) „Shareholders are stupid and impertinent - stupid because they give their money to somebody else without any effective control over what this person is doing with it and impertinent because they ask for a dividend as a reward for their stupidity". We should add that the peak of impertinence is reached when outside shareholders in opposition to management try to exert some control after all. 
Statutes giving management discretion to register a new owner of a name share are specific to Switzerland, but, at least until very recently, statutes limiting voting by any one shareholder or coordinated group of shareholders to $3 \%$ or $5 \%$ have been common elsewhere as well (as well as statutes giving multiple voting rights to parties close to management). In the case of Germany limitations on voting rights have been supplemented by the device of cross-holdings of shares. Figure 1 illustrates this phenomenon with 1991 data for a group of public corporations centered around Allianz and Münchner Rück (Munich Reinsurance). The numbers next to the arrows indicate percentages of shareholdings, e.g., Allianz having a holding $23 \%$ direct holding of Dresdner Bank and Dresdner Bank having a $10 \%$ direct holding of Allianz. ${ }^{7}$ Whatever dealings the managers of the different companies may have with each other, it seems clear that a system of cross-holdings like that presented in Figure 1 leaves no scope for outsiders to effectively use the "control rights" inherent in their shares, whether directly in voting or indirectly by tendering their shares to a potential raider. If Franks and Mayer (1995) point to the almost total absence of hostile takeovers in Germany, crossholdings, as well as voting rights limitations, provide an explanation.

Are matters so different in the United States? According to the myths that underlie the "Banks versus Markets" discussion, corporate managers in the United States are disciplined by the market, more precisely, by the prospect of hostile takeovers taking place unless they run their companies efficiently in the interests of their shareholders. In this view, dispersed outside shareholders can exercise their residual control rights by selling the company and its assets to an third party who is then free to fire the managers and reorient the company (Manne (1965), Jensen and Ruback (1983)). The market for corporate control is seen as an ongoing affair in which managers are continuously subject to takeover threats.

In fact, however, the American experience is more complex, involving active takeover markets in the twenties, the sixties, and the eighties, and practically no takeover markets at all in the intervening periods. After a pause, takeover and merger markets in the nineties have become very active again, but much of this activity seems to concern market power in product markets rather than corporate governance. The takeover phase of the eighties was tied to certain innovations in finance (junk bonds, S\&L deregulation), tax rules, judicial rulings on state anti-takeover laws; its end in 1989 was 
not only due to adverse market developments but also to the installation of anti-takeover defenses and new judicial rulings on state anti-takeover laws (Roe (1994), see also Jensen $(1991,1993)$ ).

The implementation of anti-takeover measures in the late eighties, e.g., the introduction of "poison pills" or "shark repellants" or the reincorporation of the company in the State of Delaware followed the same pattern and had the same purpose as the introduction of voting rights limitations in Germany and Switzerland or the introduction of management discretion in the registration of new owners of name shares previously in Switzerland. In each case, an incumbent management uses its sway over shareholders' meetings to obtain statute changes that protect them from outside interference. The judicial tools used are different, but this should not obscure the basic functional similarity. In each case, in the United States ${ }^{8}$ as in continental Europe, ongoing changes of statutes are used to buttress management independence from outside control and to dilute or void the control rights of outside shareholders.

There is nothing surprising about this. The theory of the market for corporate control as a mechanism for disciplining managers starts from the observation that, with dispersed shareholdings, shareholders' meetings are dominated by management; shareholders find it simply too costly to organize an opposition against management. However this observation applies to management proposing statute changes just as it applies to management proposing, e.g., miserly dividend payments. This includes statute changes that dilute or void the control rights of outside shareholders. Given the stake that management has in such statutes, we should expect such changes to take place whenever management considers them convenient or necessary. This undermines the theory of the market for corporate control as a mechanism for disciplining managers; implicitly this theory assumes that the problem for which the takeover mechanism is to provide a remedy, namely the impotence of dispersed shareholders vis-à-vis management, does not arise when management proposes antitakeover amendments to the corporate charter. In the absence of legal restrictions this assumption is problematic.

Legal restrictions do make some difference for the ability of American as opposed to Continental European or Japanese managers to immunize themselves against the threat of outsiders taking control of their companies. ${ }^{9}$ But this does not necessarily mean that American corporate managers 
are subject to more outside control than their European or Japanese counterparts. As in the case of the Japanese bond markets referred to above, organized stock markets provide companies with a device to reduce their dependence on particular financiers. In a system with arm's length relations between market institutions and the company, going public provides an outside option to the entrepreneur or manager who feels threatened by bankers, venture capitalists, or not so silent partners meddling with his business (for a picturesque example see Pickens (1987)). To the extent that legal restrictions protecting shareholders serve to make the market available for this purpose, they actually help incumbent management to emancipate itself from financiers who want to have an active say in company affairs.

\section{Allocative Implications of Management Autonomy}

\subsection{Does Lack of Outside Control Lead to Underinvestment?}

The preceding account of entrepreneurial and managerial attitudes and behaviours suggests that the exchange of control for outside finance plays rather less of a role than the contract-theoretic approach to finance would seem to indicate. As indicated by the introductory quote from Shleifer and Vishny (1997), this should make outside financiers reluctant to provides funds to firms, at least to provide them on terms where control is important. Empirically we should therefore observe a prominence of internal finance in the financing of investment. We should also a observe a dominance of debt finance, in particular secured debt finance (loans or bonds) over share finance. It would be nice to have precise numbers on this. Using a flow approach to disentangle sources of funds, Mayer (1988, 1990) reports that in terms of macroeconomic aggregates in a large number of developed countries in the period 1970 - 1985 the share of real investment financed by retentions ranged between $50 \%$ and $100 \%$, with some differences between countries, perhaps even between financial systems ("banks versus markets"!?), where however these differences seem less significant than the overall observation that retentions are important. Mayer lists credit instruments, loans and bonds, as the second most important source of funds, with shares ranging between $10 \%$ and $50 \%$; in contrast the financing conribution of share issues is reported to be negligible in terms of aggregates - in the 
"market-oriented" systems of the United States and the United Kingdom as well as in the "bankoriented" systems of Germany or Japan.

Unfortunately, there is an upward bias in Mayer's assessment of the role of retentions. His numbers for retentions include depreciation including the depreciation attributable to loan-financed investment (Wenger (1996), Hackethal and Schmidt (1999)). Even so, his work contains two important lessons: (i) To assess the financing contribution of the stock market, one must look at flows and distinguish between retentions and new stock issues. To the extent that corporate investment is financed by retained earnings, large stock market capitalizations may reflect management discretion over retentions rather than the financing function of the stock market. ${ }^{10}$ (ii) In terms of aggregate flows, the financing contribution of organized stock markets is relatively small: The bias from the treatment of depreciation affects the comparison of retentions with other sources of funds, but not the relative assessment of credit instruments and shares.

At the microeconomic level, the role of internal finance is reflected in the sensitivity of firm investment to cash flow as reported by Fazzari et al. (1988) for the United States, by Elston (1997) for Germany, and by Hoshi et al. (1991) and Hall and Weinstein (1996) for Japan. The cash flow sensitivity of investment tends to be the more pronounced the smaller the company is. This reflects the fact that the larger, more established corporations offer better security and therefore find it easier to get loans to bridge them over a cash flow shortfall. To the extent that cash flows shocks of small and large companies are correlated through the business cycle, it may also reflect changes in borrower quality requirements with the business cycle, i.e., banks shifting funds in bad times from small, presumably risky firms to large highly-rated companies.

How are we to assess the allocative impact of these findings? According to Myers and Majluf (1984), the dominance of internal finance in the "pecking order" reflects the fact that internal finance involves lower agency costs than any other form of finance suggesting that the "pecking order" is in fact quite efficient. In the interpretation given here, the dominance of internal finance reflects the convenience of internal finance for management; however this in itself may be a way of treating shareholders à la Fürstenberg, i.e., of not providing them with a suitable return on their investment. To the extent that this is the case, the agency costs of retentions cannot be deemed to be zero but instead must be 
linked to the difficulties of obtaining outside equity ex ante when investors less stupid than Fürstenberg's shareholders anticipate that ex post they will have little influence on the division of earnings between retentions and dividends. In this respect, Jensen's (1986) criticism of excessive retentions of "free cash flow" captures the agency problem of retentions better than the Myers-Majluf analysis, which fails to consider the conditions of prior issues of external equity.

The literature interprets the cash flow sensitivity of investment in terms of a rationing of funds (Fazzari et al. (1988), Hoshi et al. (1991), Gerke et al. (1995)). Firms are deemed to have many profitable investment opportunities. However, their ability or their willingness to raise external finance is limited, and therefore they are constrained by their self-financing ability. Even where they have access to credit, credit lines will depend on their net wealth positions, so cash flow affects investment opportunities indirectly through credit lines as well as directly through the ability to self-finance. The inherent view seems to be that a substantial reliance on internal finance must give rise to insufficient investment as internal funds do not exhaust profitable investment opportunities. In terms of the statement from Shleifer and Vishny (1997) cited in the introduction to this paper, the inability or unwillingness of managers to commit to a credible transfer of control rights to outside financiers restricts the funds flowing into business investments.

I have difficulties with this assessment. A sytem based on internal finance can exhibit overinvestment as well as underinvestment. There is no a priori reason why internal financing capacity should always fall below profitable investment opportunities. If indeed cash flow exceeds a firm's profitable investment opportunities, retentions may lead to overinvestment. The phenomenon is familiar from the American oil companies in the early eighties: High cash flow from known wells served to finance large-scale drilling activities with recognizably poor returns; this was continued until the takeover wave of the mid-eighties forced a reorganization of the industry. This sort of overinvestment phenomenon is at the heart of Jensen's (1986) "free cash flow" hypothesis: Management is prepared to invest "free cash flow" inefficiently if this serves to keep the funds in the firm rather than distribute them to shareholders.

From the perspective of Jensen's "free cash flow" hypothesis, the rationing interpretation of empirical results on the cash flow sensitivity of investment is unwarranted. If we assume that investment 
opportunities are not correlated with cash flows (as this literature does), the observed correlations of investment spending and cash flow can be due just as much to excessive investments by firms with large cash flows as to insufficient investment by firms with small cash flows.

In trying to evaluate over- and underinvestment effects of the predominance of internal finance, one has to distinguish between aggregate effects and structural effects. In terms of aggregates, I conjecture that in advanced economies the overinvestment effect from the "free cash flow" problem will dominate the underinvestment effect in the long run. To be sure, a less developed economy with little capital will at least temporarily have too little investment if investment is constrained by internal financing capacity. However we know from standard growth theory that on efficient growth paths rates of return on capital will eventually exceed real growth rates, which implies that aggregate returns to capital exceed aggregate investment. This suggests that in the long run, aggregate earnings of the corporate sector should exceed efficient levels of aggregate investment, in which case "excessive" retentions may give rise to overinvestment on aggregate.

\subsection{Structural Change and the Allocation of Funds for Investment}

For mature economies, the availability of finance for structural change may be more important than the behaviour of aggregates. An analysis that focuses on aggregates neglects the role of structural change in the economy. Different firms and different sectors have different cash flows and different investment opportunities. In the cross-section of firms in the economy, cash flows and investment opportunities are not always correlated. This raises the possibility that one may have overinvestment and underinvestment phenomena at the same time, overinvestment phenomena at mature firms milking their cash cows, underinvestment phenomena at new firms that do not yet have enough profits from sales of established products to finance their development activities. The two effects, overinvestment at old firms and underinvestment at new firms, are then but two sides of the same coin, namely the imperfect correlation of cash flows and investment opportunities across firms.

If investment opportunities are particularly favourable in those firms and industries that also have high cash flows, there is not much of a problem. Consider the case of Germany in the fifties: Production 
capacity was scarce, consumer needs as well as production technologies were by and large known, and the main allocation problem was to direct funds into those lines where additional production capacity was most needed. In such a situation, current profits would seem to be good indicators of scarcity and hence of further investment needs. One suspects therefore that the reliance on internal funds in these years (retained earning and accelerated depreciation with significant tax subsidies) has not created too much of a distortion in the allocation of funds. ${ }^{11}$

Difficulties arise when cash flow is not a good signal of investment needs. However even in this case we cannot simply assume that a system based on internal finance will necessarily impede the requisite structural change in the economy. Structural change often takes the form that an established large company buys up a small new company and implements their developments on a large scale. As yet we have little understanding of the economics of this process. On the one hand there are spectacular failures such as Daimler-Benz in the eighties trying to become a "technology conglomerate" by buying up an electrical-appliances producer (AEG) and three airplane and armaments producers (Dornier, MBB, and Fokker) and then financing their losses for a few years from profits in automobiles. On the other hand there have also been remarkable successes such as Swiss Bank Corporation buying up the derivatives firm O'Connor and using the occasion to revolutionize their entire asset allocation system relying on risk management techniques and personel from their acquisition. Traditional chemical and pharmaceutical companies buying up small biotech ventures might be another positive example.

These considerations suggest that we should reassess the task of the financial system. In a highly developed economy in which returns on capital exceed efficient investment, the task of the financial system may not so much be that of channelling funds from the household sector to firms as to channel funds from firms with an excess of cash flow over profitable investment opportunities to firms with a shortfall of cash flow below profitable investment opportunities. One possibility to fulfil this task is to distribute earnings to the household sector through interest payments, dividend payments and takeover premia and then to have the household sector reinvest its funds in other firms. Another possibility is to have firms with "free cash flow" engage in mergers and acquisitions so as to finance new activities directly. The relative pros and cons of these two alternatives are not altogether clear. 
To assess a financial system, one must go beyond the consideration of individual firms à la Fazzari et al. (1988) or the consideration of aggregates à la Mayer (1988) and look at the mechanisms of financing structural change. If Mayer (1988) suggests that in the United States in the years 1970-1985 only $1.1 \%$ of investment was financed by net issues of shares, this aggregate is computed as the difference of positive share issues of new firms and "negative share issues" in the context of corporate takeovers and the like. In the United States, forced distributions to households through takeover premia went together with new share issues in new sectors such as biotechnology or software. This structural effect is overlooked if one only sees the $1.1 \%$ and compares it, e.g., to the corresponding aggregate number of $0.6 \%$ for Germany.

As yet we do not have a good theoretical understanding of the different mechanisms of structural change and the role of finance in structural change. A few points seem obvious even without a sophisticated theory: First, a system involving more distributions of funds to households and reinvestments of funds by households will have more decentralized decisions. Such a system is likely to provide for more experimentation. Many experiments will be flops, but (i) there will be more reliance on the law of large numbers, and (ii) there will be less of a chance that some really good opportunity is missed simply because nobody bothers to look at it. Secondly, a system involving more distributions to households and reinvestments by households is likely to spread its funds more thinly; this may be disadvantageous in areas where there are significant economies of scale. In contrast to these considerations, a system relying on CEOs of established companies to reinvest significant sums outside of their own fields of expertise is less able to explit the law of large numbers but more able to exploit scale economies moving quickly once a success has been identified. ${ }^{12}$

Another effect to be considered is the difference between the functioning of a new organization as a company of its own and as a division of some established corporation. The biotechnology company that stands on its own is subject to different incentives, control, and financing prospects than one that has been taken over by a more traditional pharmaceutical company. Insights from the theory of vertical integration (see, e.g., Grossman and Hart (1986)) should be useful for understanding this, but as yet I can do no more than point to the problem. 


\subsection{Agency Costs of "Free Cash Flow" - Are There Any? What Are They?}

Jensen $(1986,1993)$ emphasizes the agency costs of a system based on retentions and reinvestment of funds by incumbent management. He argues that investment decisions in such a system are likely to be inefficient because managers neglect the portion of the returns on investment that accrue to shareholders rather than themselves.

I find this argument unconvincing, at least in the form in which it is given. The notion that the marginal returns on investment accrue to shareholders rather than managers is somewhat at odds with the notion that managers have discretion over the use of "free cash flow". Presumably management's discretion over the use of "free cash flow" extends from the present into the future. This means that the marginal returns to today's investment decision will accrue to the future maneuvering mass of managers. In a world in which management has discretion over the use of "free cash flow", management is in fact a kind of residual claimant. Shouldn't we then expect the reinvestment decisions taken by management to be efficient?

Absurd though it may seem, this question is not so easy to dispose of. Indeed the most obvious objections are invalid: First, the argument given above that anticipations of management control over retentions makes it hard to raise equity finance in the first place rests on the assumption that such equity finance is needed. In a world in which investment is financed by retained earnings, either directly or indirectly through corporate acquisitions and subsequent intra-firm subsidization, such outside equity finance is not actually needed. Second, the argument that internal subsidization in the American oil industry in the early eighties was obviously inefficient neglects the significance of consumption on the job. If management got consumption value out of using its power to play with money in this particular way, what was so inefficient about that? Shocking though this question may seem, it highlights the point that many spontaneous reactions to such observations are driven by fairness rather than efficiency considerations. For fairness reasons, we may consider it outrageous if management expropriates shareholders and indulges in consumption on the job (Adams (1994), Wenger (1996)); however it is important to separate this from the assessment of efficiency. 
To get at the efficiency implications of management discretion over the use of "free cash flow", one has to start from the observation that money in the company till is not the same as money in the manager's pockets. Residual claimancy on money in the company is not the same as residual claimancy on money for private use. Given this difference, the following effects are likely to be relevant:

- The incumbency horizon of management is shorter than the horizon of the firm. A manager who becomes CEO at the age of 50 (or later) and expects to retire at 65 (or earlier) will try to follow strategies that he enjoys while he is there even if they may cause problems for the company thereafter (Noll and Bachmann (1988)). From a price theoretic perspective, the problem is that the transfer of control from one CEO to the next is not accompanied by any compensation that would correspond to the effective value of the company at the time of the transfer.

- To the extent that the manager's position is less than secure, he may have a tendency to use company resources to buttress it. For example he may invest in assets that permit the easy accumulation and decumulation of hidden reserves because this makes it more difficult to assess his true performance. If a company like Thyssen at the time of the Krupp takeover attempt in March 1997 was said to hold (mainly hidden) reserves of DM 4 billion in real estate (with a stock market capitalization of DM 12 billion, see below), the rationale would seem to be that such reserves provide for smoothing and presumably for protection from altogether too drastic consequences of cash flow fluctuations. To the extent that such protection is intended to preempt nasty questions about profit shortfalls, one may expect investment in such assets to be excessive. If strategy changes are thereby precluded or delayed, this is a further sources of distortions.

Our thinking about these issues is impeded by the fiction, which is implicit in most discussions of corporate finance and corporate control, that "management" consists of a single person. The notion that the "market for corporate control" takes place on Wall Street (if at all) overlooks the fact that career competition, boardroom infighting, and decisions on CEO succession provide an internal market for corporate control which in many cases is just as competitive as any external market. Managers may be unanimous in keeping the outsiders out, but this does not mean that they are unanimous in anything else, especially if the matter at issue may be used to eliminate a potential 
rivals. Agency problems of the Jensen-Meckling (1976) laziness type are perhaps more effectively controlled by rivals trying to expose each others' weaknesses than by any outsider monitoring.

Before we proceed to name the effects discussed above as obvious sources of inefficiencies from excessive management discretion, we therefore need to check whether these inefficiencies may not be curbed by internal control mechanisms. As yet we know very little about these. Jensen (1993) claims that internal control mechanisms in large American corporations are ineffective, but the theoretical status of his argument is unclear. As indicated by the juxtaposition of the Daimler-Benz and Swiss Bank Corporation examples above, it is not enough to show that a given system leaves room for mistakes; one has to compare the distribution of such mistakes to the distribution one would have under an alternative system.

In this context, it is of interest to recall the empirical findings of Kaplan (1994a,b), whereby the effects of poor performance of a company on management turnover in the United States, Japan and Germany are roughly comparable, i.e., the differences of systems that are stressed in the "banks versus markets" literature are not obviously of great importance. If we think of corporate governance in Germany in terms of networks of insiders along the lines suggested by Figure 1, Kaplan's findings suggest that these insiders provide each other with mutual control as well as mutual protection against interference from outsiders, and moreover, the control policies implemented are not all that different from those in the United States.

In terms of the brute mechanics of control, Kaplan's findings are not all that surprising. On the one hand, a person's being appointed to do a job implies that mere professionalism will provide this person with a certain leeway in how to handle the job - at least as long as things do not go badly. Excessive interference would endanger the division of labour which is the rationale for the person's appointment in the first place. A striking example of this consideration is provided by Daimler-Benz in the eighties. The diversification strategy was pursued by the chairman of Daimler-Benz over the opposition of chairman of the Daimler-Benz supervisory board who at the same time was the chairman of Deutsche Bank, in control - directly or indirectly - of roughly $50 \%$ of Daimler-Benz's outstanding stock. Given that Daimler-Benz at the time was very profitable and did not need external 
funds for its acquisitions, the chairman of Deutsche Bank preferred to be overruled rather than interfere with the job of the chairman of Daimler-Benz.

On the other hand, if things turn out badly, the other members of the network have an incentive to interfere before the damage spills over to them. Given that downturns in profits or market values provide the same sort of signal as in the American environment, the dependence of this sort of interference on such information should not be all that different.

This being said, in any such system of insiders mutually controlling and mutually protecting each other, incumbency is likely to be a significant source of distortions. People who have been there for a while tend to pursue their own activities and to neglect new opportunities, sometimes because their perceptions are biassed towards the things they know, sometimes because they do not want to nurture future rivals. A well known example of this bias is provided by IBM's decision in the early eighties to give priority to mainframe development over personal computers. A parallel example is provided by the relative slowness of continental Europe in biotechnology: Here the traditional chemists who dominated the large chemical and pharmaceutical corporations found it difficult to appreciate the new paradigm for pharmaceutical research that underlay the development of biotechnology; now of course everybody is trying to catch up.

In this context, the example of successful structural change within a given institution that I gave above, namely the comprehensive introduction of modern risk management techniques at Swiss Bank Corporation, seems to be an exception that proves the rule. According to Schütz (1998), the wholesale transformation of SBC following the O'Connor acquisition could take place because (i) this happened to be convenient for the career aspirations of the person in charge, and, just as importantly, (ii) the potential opposition to this transformation happened to be politically weak, a few spectacular losses on commercial loans in the late eighties having discredited the more traditionalist loans department. In this case too, the internal politics of the organization seem to have been at least as important as the consideration of merit of the route that was taken. 


\section{The Politics of Corporate Control}

\subsection{The Natural Alliance of "Stakeholder Interests" and Incumbent Management}

In March 1997, Krupp, with the assistance of Deutsche Bank, made a hostile tender offer for Thyssen AG. Prior to the offer, the stock market capitalization of Thyssen was about DM 12 billion. The offer amounted to DM 15 billion. Thyssen management started a public campaign arguing (i) that Krupp was trying to hurt shareholders by bidding DM 15 billion when in fact the company was worth DM 18 billion and (ii) that Krupp was threatening "the company", its workers, managers, ..., by proposing to plunder its assets in order to pay the shareholders. The second argument was very successful. Politicians from left to right, from state government to federal government, union leaders, the media... all protested against the Krupp move and clamoured to have the tender offer withdrawn. After a week's negotiations under the "mediation" of the state government, Krupp indeed withdrew its offer in return for an agreement to merge the two companies' steel operations. The stock market capitalization of Thyssen returned to the level of DM 12 billion where it had been before the tempest started. No complaint was raised in public that this deprived shareholders of DM 3 billion, nor had there been any further complaint about the fact that the German economic and financial system was not competitive enough to force Krupp to raise its bid to the "true" (?) value of DM 18 billion.

This episode illustrates a common phenomenon: Incumbent managers who try to buttress their positions will regularly find allies in the political system, labour, the media, the judiciary, and even the universities. ${ }^{13}$ In the United States, the mechanism can be observed in the reactions of the political system and the judiciary to the takeover movment of the eighties (Jensen (1991), Roe (1994)). In Switzerland, one may point to the political system's and the judiciary's long-lasting acceptance of statutes giving managers the right to refuse new holders of name shares without giving reasons, or to the legal provision requiring banks to use proxy votes in favour of corporate management unless they have explicit instructions to the contrary. In Germany, the Krupp-Thyssen affair is not an isolated episode but part of a long tradition ranging from legally mandated limits on dividend payments in the thirties to the present-day unfavourable treatment of minority shareholders by the legislature and the judiciary or the rules governing cross-holdings (Wenger (1996)). In each country the details are different, but the overall mechanism is the same. 
Jensen (1991) seems to regard the treatment of corporate control by the political system and the judiciary as the result of a misunderstanding, a mistaken reaction to populist rhetoric about "plundering assets", without understanding for the systemic implications. In contrast I share the view of Roe (1994) whereby the alignment of politicians, judges, etc. with corporate management reflects systematic effects rather than misunderstanding. In the Krupp-Thyssen affair, the two companies have by now been merged after all - without any cash payment to shareholders. The sums that were thereby saved are available for others, workers who get a sweetening for the downsizing that will occur, politicians who need to put a costly problem into somebody else's purse, representatives of "culture" in search of a sponsor, and of course the management of the merged company that decides over their use.

The regulation of corporate governance has important distributional implications: Funds that are distributed to shareholders are not available to anybody else. Anybody with an eye on a firm's funds will therefore be opposed to these funds being paid out to shareholders, whether as dividends or as takeover premia. This distributional conflict is an important element of the discussion about "stakeholder interests versus shareholder value" in public corporations. It is particularly pronounced in mature companies when cash flows exceed investment needs within the company's area of competence. In such companies, e.g., workers and their representatives as "stakeholders" have a natural interest in retentions contributing to the building of reserves that may help the company to avoid, delay, or at least financially sweeten layoffs if ever the company were to fall upon hard times. This "stakeholder interest" is directly opposed to the outside financier's interest in getting his money back and deciding for himself what is the most suitable reinvestment opportunity.

The political system may be seen as a stakeholder in its own right. At one level, there is an immediate financial interest, ranging from a concern about corporate income taxes ${ }^{14}$ to campaign contributions and, more generally, the ability to induce corporations to finance activities that the politician wants to get off the government budget. In the Daimler-Benz case mentioned above, the company's diversification into a "technology conglomerate", more precisely its acquisition of the ailing airplane producer MBB, enabled the government to shift expenses of the Airbus off the public purse 
and onto the shareholders of Daimler-Benz who got to enjoy rather less of the profits the company earned in automobiles. Surely the government was not unhappy to be freed of this burden!

At another level, the political system - and the media - reflect the stakeholder interests of their constituencies. Local politics in particular will reflect the workers' interests in having their companies hold reserves to smooth over potential future difficulties and delay or sweeten needed adjustments. To the extent that, e.g., layoffs affect not just the workers, but the entire community, shop keepers, real estate owners, and the government itself, this interest is actually shared by all of "Main Street". As discussed in detail by Roe (1994), the proprietory attitude of "Main Street" towards "its" company provides the basis for a certain deference towards the company's management and for hostility against the claims of outsiders, in particular financiers, against the company.

Stakeholders have the advantage that they are easy to identify. They tend to be concentrated in certain locations, with little intention to move if they can help it. Outside shareholders in contrast are difficult to identify and to see as actual people. They tend to be dispersed. Their identities and locations change with every stock market transaction. Therefore, politicians, in particular local politicians, tend to align with stakeholders rather than shareholders: Stakeholders vote in well-defined constituencies, shareholders do not. Stakeholders also buy newspapers in well-defined constituencies, so for journalists as well they provide an easily identified clientele with a significant element of human interest. This explains why so often we observe the media as well as leading politicians rallying on the side of incumbent management when the latter asserts its "responsibility for the overall economy" ${ }^{15}$ as a way of rebutting shareholder interference.

From a theoretical perspective, the assertion of stakeholder interests involves a valid point. The decisions of corporate management do affect the company's stakeholders, some of them directly, some of them indirectly through pecuniary and nonpecuniary externalities (Shleifer and Summers (1988)). In the absence of explicit contracts regulating these effects, this may justify some consideration of stakeholder interests in corporate governance.

However the argument carries less far than may appear at first sight. It involves two important biases. First, it neglects all the stakeholders of companies that are yet to be created, that would find it easier 
to obtain external share finance if "free cash flow" at mature companies was distributed to shareholders and then reinvested through the market. Characteristically, when Shleifer and Summers (1988) talk about shopkeepers and real estate owners in a depressed company town after a closure decision, they neglect to talk about the shopkeepers and real estate owners in the thriving new company town where funds have gone instead. This is akin to the incumbency bias we observe in decision making within companies: Stakeholders from past and present activities are in a good position to make their case known; stakeholders from potential future activities are not yet known, and their interests cannot yet be articulated. This point is directly related to the discussion of allocative distortions in Section 3. If one thinks of reinvestments of retentions through mergers and acquisitions as a vehicle for structural change in an otherwise closed corporate system, presumably the candidates that one is looking for should not be problem cases in search of someone with cash to pay for their difficulties; in fact this was the common feature of all the major acquisitions in the diversification strategy of Daimler-Benz in the eighties.

Secondly, the argument for the consideration of stakeholders in corporate corporate governance neglects the fact that among all the parties that are involved with a firm, the outside shareholder is the one whose contractual protection is weakest. He has provided funds to the company in return for a piece of paper that entitles him to little more than a vote in future decisions of shareholder meetings. As noted by Shleifer and Vishny (1997), any financier has the problem that once he has provided his funds, he becomes a nuisance as his only remaining function is to be paid off. With nothing else to be expected from the financier, his debtor would like to get out of his obligation if he could. Given that he sits on the cake that is to be distributed, it is not hard for him to find political allies who will join in disputing the financier's claims if only they can get a piece of the cake. When the financier is an outside shareholder whose claim is not even well defined, the result seems a foregone conclusion. The "residual power" of management to disenfranchise outside shareholders is significantly related to its ability to rally stakeholder interests to its support in political and judicial controversy. 


\section{$\underline{4.2 \text { Corporate Control and Banks: A Second Look }}$}

In discussing the politics of corporate control, Roe (1994) points to differences between the United States on the one hand and Japan or Germany on the other, and suggests that in the United States control of corporate managers is weaker because the support of "Main Street" against "Wall Street" has enabled management to induce the political system to weaken the power of the financial sector. This is contrasted with Japan or Germany where there are fewer regulatory constraints on financial institutions and therefore the control of corporate managers by banks is said to be more effective.

I am not convinced that this interpretation of cross-country differences is appropriate. Implicitly it assumes that banks in Germany or Japan act as the representatives of final investors - delegated monitors à la Diamond (1984). This is questionable. The orthodox view of banks as delegated monitors and controllers of firms presumes not only that firms are willing to submit to such control but also that banks are eager to engage in it. Leaving aside the question discussed before whether firms are willing to accept control by banks, one may also doubt the latter presumption. Firms with ample funds for investment make interesting clients for a bank's mergers \& acquisitions department. In a financial system that is channelling funds from firms with surplus cash to firms with insufficient cash, financial institutions will offer their services and obtain appropriate fees. Such institutions have a vested interest in protecting management autonomy vis-à-vis shareholders, more precisely, in protecting management discretion over retentions, which provide the financial basis for mergers and acquisitions. Fürstenberg after all was a banker!

This consideration would explain why in large German corporations the banks' proxy votes on behalf of their depositors seem to be used more as a tool to protect management than as a tool to impose the bank's will on the company (Baums und Fraune (1995), Wenger (1996)). Whereas empirical research on the effects of bank proxy voting on firm performance is inconclusive, ${ }^{16}$ Baums and Fraune (1995) find that prominence in proxy voting at a company's shareholders' meeting is correlated with prominence in underwriting the company's securities offerings, suggesting that in fact there is a trade of protection against fees for services. Given the small number of observations they have, it is too early to assess the validity of this conjecture. It does however suggest that the 
concentration of the literature, e.g., Edwards and Fischer (1994), on the financing role of financial institutions may be misplaced. The services provided by financial institutions may be as important in shaping bank-firm relations. Moreover the lesser transparency of quality-price tradeoffs in services may make it easier to maintain special relations in these markets.

Similar roles have been played by investment banks such as J.P. Morgan in the United States until the early eighties or Mediobanca in Italy. Quite generally, banks should perhaps be seen as one set of players in the network of insiders. As such they will not be averse to interfering with a firm in order to obtain a profit for themselves, but as a general rule they will contribute to the protection of the system against outsiders. A remarkable illustration of this is provided by Penati and Zingales (1998), who report that in the restructuring of the Ferruzzi Group in Italy, the investment bank Mediobanca used its sway over the restructuring process to even get the priority of creditors over shareholders reversed; the creditors in question were outsiders, the shareholders insiders of the system.

If we regard banks - more precisely, bankers - as one set of players in a system of insiders, we find that the distinction between "Wall Street" and "Main Street", between finance and production is rather less important than the distinction between outsiders and insiders. If Deutsche Bank in its relations to an industrial company is subject to less regulatory constraint than a financial institution in the United States, this does not mean that in Germany the club of insiders as a whole is less protected by the political system than in the United States. Indeed the contrary is true. As documented most extensively by Wenger (1996), protection of insider control by the political system and the judiciary is significantly more effective in Germany than the United States. Outsiders have practically no scope whatever for exerting control. The United States in contrast do have these phases once every few decades when financial innovation activates the "market for corporate control" and it takes a few years before new anti-takeover measures are installed. Even outside of such takeover waves, regulation of corporate governance in the United States seems to be rather more friendly towards outside shareholders than in any continental European country (la Porta et al. (1998)).

I wonder whether the difference may be related to the different forms of organization of the financial sector. In the fragmented financial system of the United States, brokerage firms and investment banks do provide a lobby that is interested in an active market for corporate control. Their influence is 
notable at the level of federal politics as well as the SEC. In contrast, in a universal-banking system this interest is only one of many concerns of a given institution. If a universal bank is interested in safeguarding its cheap deposit base or in having lucrative fees for services from firms, they may find that these concerns outweigh whatever they might gain from a functioning market for corporate control. Whereas Roe (1994) regards the fragmentation of the American financial system as a source of its weakness in exerting control over firms, the argument here would suggest that this very fragmentation may help explain why the American political and regulatory system is somewhat less hostile to outsiders than others. In this context it should also be noted that, as discussed in Section 2.3 above, the more shareholder-friendly regulatory structure in the United States may actually be in the interest of a management that relies on the market as a mechanism to emancipate itself from the influence of financiers who want to have a direct say in the firm's affairs.

\subsection{The Interplay of the Corporate Sector and the Political System}

Debates about "stakeholder interests versus shareholder value" tend have two rather peculiar features:

- They rarely address the role of management as a stakeholder of its own.

- They rarely address the procedural question of how one is to check whether management is living up to its responsibilities on either account.

These omissions are not coincidental. They serve to divert attention away from the fact that management is a player in its own right, interested in keeping control over the company's assets and wanting to remain in charge. The chief executive officer of a coporation may defend himself in one year against shareholder interference by citing stakeholder interest, and in the next year announce layoffs in the name of shareholder value. On both occasions he really means the same thing, namely his decisions are nobody else's business. By focussing on the substance of what interests "the firm" should cater to, the debate on stakeholders versus shareholders diverts attention from this role of management itself.

Interestingly, professed concerns for stakeholders have rarely had implications for governance. Codetermination of labour in Germany is the major exception. Given the prominence of rhetoric on 
the public responsibilities of large corporations, one may wonder why we do not observe more attempts to institutionalize the consideration of „stakeholder interests“ in corporate governance.

I see several answers to this question. First, the polity may be too weak to impose governance structures against the wishes of corporate management. This would, e.g., be the case when different jurisdictions are competing to be the seats of corporate headquarters and try to attract companies by offering a management-friendly reguzlatory environment. The role of the State of Delaware and its success with this strategy have been much discussed in this context (Jensen (1991), Roe (1994)); incorporation in this state seems to be one of the moves available to managers trying to change the rules of the game they play with their shareholders.

Secondly, politicians and other stakeholder representatives may be reluctant to be visibly drawn into firm decision making, assuming a co-responsibility for policy choices that will to some extent lie outside their areas of expertise and over which sometimes they have no control after all. In terms of their own accountability to their constituents such co-responsibility would seem to put them into an awkward position.

Thirdly, it may actually be quite nice for politicians and other stakeholders to know that there is a party with control over resources to whom they can turn when they need to unload a costly problem. Daimler-Benz taking MBB and the further costs of the Airbus off the German government's budget provided a nice escape from awkward discussions about the costs of industrial policy. On a more regular, day-to-day basis we do observe large corporations accepting „obligations to the community“ that are not in any sense legal obligations, but simply part of an informal give-and-take with the political system. The informality of such give-and-take is one of its charms for politicians as it reduces transparency and allows them to reduce accountability for at least some of the costs they generate.

In terms of the functioning of the overall economic and political system, informal give-and-take has the advantage that it saves on transactions costs. One can exploit the gains from cooperation in a long-term relation with repeated interactions. This permits, e.g., the functioning of the German apprenticeship system in which companies train people without any guarantee that they will stay with them, largely as a result of political pressure and peer pressure, without any need for formal 
legislation. At the same time though the lack of transparency about such dealings makes it difficult to hold anybody responsible for costs. Presumably the German corporate sector's acceptance of the apprenticeship system is rewarded by the taxpayer somehow - but it is not clear how and at what cost.

An even more important concern may be in the entire system closing itself against innovation. Informal mechanisms of coordination between the political system, the corporate sector, etc. can work well if one is in a situation where everybody knows everybody else, no untoward surprises occur, and everyone knows what measures will be effective in punishing untoward behaviour. Outsiders naturally generate mistrust - one does not know how to deal with them through informal mechanisms. This makes it tempting to exclude them from any significant influence. Indeed the natural alliance of the political system, the judiciary, the unions, etc. against the assumption of control by outsiders is very much related to the fact that outsiders are difficult to fit into informal mechnisms of give-and-take. But if all control and coordination mechanisms are designed to exclude outsiders, this poses a serious danger for the overall political and social system, carrying the incumbency bias towards known activities one level further to the assessment of legitimacy on the basis of incumbency. 


\section{$\underline{\text { References }}$}

Adams, M. (1994), Die Usurpation von Aktionärsbefugnissen mittels Ringverflechtung in der Deutschland AG, Die Aktiengsellschaft 4, 148-159.

Admati, A., P. Pfleiderer, and J. Zechner (1994), Large Shareholder Activism, Risk Sharing and Financial Market Equilibrium, Journal of Political Economy 102, 1097-1130.

Aghion, P. and P. Bolton (1992), An "Incomplete Contracts" Approach to Financial Contracting, Review of Economic Studies 59, 473-494.

Barca, F. (1995), On Corporate Governance in Italy: Issues, Facts, and Agency, mimeo, Bank of Italy, Rome.

Baums, T. and C. Fraune (1995), Institutionelle Anleger und Publikumsaktiengesellschaft: Eine empirische Untersuchung, Die Aktiengesellschaft 40, 97-112.

Becht, M., and E. Böhmer (1997), Transparency of Ownership and Control in Germany, Discussion Paper No. 1997-91, Sonderforschungsbereich 373, Humboldt-Universität, Berlin.

Bhide, A. (1993), The Hidden Costs of Stock Market Liquidity, Journal of Financial Economics 34, 3152.

Bolton, P. and E.L. von Thadden (1998), Blocks, Liquidity and Corporate Control, Journal of Finance $53,1-25$

Cable, J. (1985), Capital Market Information and Industrial Performance, Economic Journal 95, 118132.

Chirinko, R.S., and J.A.Elston (1996), Finance, Control, and Profitability. An Evaluation of German Bank Influence, mimeo, California Institute of Technology. 
Crouzet, F. (ed.) (1972), Capital Formation in the Industrial Revolution, Methuen, London.

Dewatripont, M. and J. Tirole (1994), A Theory of Debt and Equity: Diversity of Securities and Manager-Shareholder Congruence, Quarterly Journal of Economics 109, 1027-1054.

Diamond, D. (1984), Financial Intermediation as Delegated Monitoring, Review of Economic Studies $51,393-414$

Edwards, J. and K. Fischer (1994), Banks, Finance and Investment in Germany, Cambridge University Press, Cambridge, UK.

Edwards, J., and S.Ogilvie (1996), Universal Banks and German Industrialization: A Reappraisal, Economic History Review 49, 427-446.

Elston, J. (1997), Investment, Liquidity Constraints and Bank Relationships: Evidence from German Manufacturing Firms, mimeo, California Institute of Technology.

Fazzari, S., G. Hubbard, and R. Petersen (1988), Financing Constraints and Corporate Borrowing, Brookings Papers on Economic Activity, 141-195.

Feldenkirchen, W. (1979), Banken und Stahlindustrie im Ruhrgebiet - Zur Entwicklung ihrer Beziehungen 1873-1914, Bankhistorisches Archiv 5, 26-52.

Fischer, K. (1990), Hausbankbeziehungen als Instrument der Bindung zwischen Banken und Unternehmen: Eine theoretische und empirische Analyse, Doctoral Dissertation, University of Bonn.

Fohlin, C. (1996), The Rise of Interlocking Directorates in Imperial Germany, California Institute of Technology, Social Science Working Paper No. 931, Revised Version, Pasadena, CA. 
Fohlin, C. (1997), Universal Banking Networks in Pre-War Germany: New Evidence from Company Financial Data, Ricerche Economiche 51, 201-225.

Fohlin, C. (1998a), Relationship Banking, Liquidity and Investment in German Industrialization, Journal of Finance 53.

Fohlin, C. (1998b), Financial System Structure and Industrialization: Reassessing the German Experience Before World War I, California Institute of Technology, Social Science Working Paper 1208, Pasadena, CA.

Franks, J. and C. Mayer (1995), Ownership and Control, in: H. Siebert (ed.), Trends in Business Organization: Do Participation and Cooperation Increase Competitiveness?, Mohr(Siebeck), Tübingen, 171-195.

Gerke, W. (1995), Problem mittelständischer Unternehmen beim Zugang zum Kapitalmarkt, Nomos, Baden-Baden.

Gerschenkron, A. (1962), Economic Backwardness in Historical Perspective, Harvard University Press, Cambridge, MA.

Gessner, V. et al. (1978), Die Praxis der Konkursabwicklung in der Bundesrepublik Deutschland, Bundesverlag, Köln.

Gorton, G., and F.A. Schmid (1996), Universal Banking and the Peformance of German Firms, mimeo, Whartin School, University of Pennsylvania.

Grossman, S. and O.D. Hart (1980), Takeover Bids, the Free-Rider Problem, and the Theory of the Corporation, Bell Journal of Economics 11, 42-64.

Grossman, S. and O.D. Hart (1986), The Costs and Benefits of Ownership: A Theory of Vertical and Lateral Integration, Journal of Political Economy 94, 691-719. 
Hackethal, A., and R.H. Schmidt (1999), Financing Patterns: Measurement Concepts and Empirical Results, Discussion Paper No. 33, Working Paper Series: Finance and Accounting, University of Frankfurt.

Hall, B. and D. Weinstein (1996), The Myth of the Patient Japanese: Corporate Myopia and Financial Distress in Japan and the United States, NBER Discussion Paper, National Buearu of Economic Research, Cambridge, MA.

Harhoff, D. (1998), Die Finanzierung von Innovationsprojekten, in: N.Franke and C.F.von Braun (eds.) Innovationsforschung und Technologiemanagement, Springer, Berlin Heidelberg, New York.

Harhoff, D. and T. Körting (1998), How Many Does it Take to Tango? Discussion Paper, ZEW Mannheim.

Hart, O.D. (1995), Firms, Contracts, and Financial Structure, Oxford University Press, Oxford.

Hellwig, M. (1991), Banking, Financial Intermediation and Corporate Finance, in: A. Giovannini and C. Mayer (eds.), European Financial Integration, Cambridge University Press, Cambridge, UK, 33-63.

Hellwig, M. (1998), Allowing for Risk Choices in Diamond's "Financial Intermediation as Delegated Monitoring", mimeo, University of Mannheim.

Hoshi, T., A, Kashyap, and D. Scharfstein (1990), Bank Monitoring and Investment: Evidence from the Changing Structure of Japanese Corporate Banking Relationships, in: R.G. Hubbard (ed.), Asymmetric Information, Corporate Finance, and Investment, University of Chicago Press, Chicago, 105-126. 
Hoshi, T., A. Kashyap, and D. Scharfstein (1991), Corporate Structure, Liquidity and Investment, Quarterly Journal of Economics 106, 33-60.

Jarrell, G., J.A.Brickley, and J.M.Netter (1988), The Market for Corporate Control: The Empirical Evidence Since 1980, Journal of Economic Perspectives 2, 49-68.

Jeidels, O. (1905), Das Verhältnis der Deutschen Grossbanken zur Industrie, Duncker\&Humblot, Leipzig.

Jensen, M. and W.H.Meckling (1976), Theory of the Firm,: Manegrial Behavior, Agency Costs and Capital Structure, Journal of Financial Economics 3, 305-360.

Jensen, M. and Ruback, R. (1983), The Market for Corporate Control: The Scientific Evidence, Journal of Financial Economics 11, 5-50.

Jensen, M. (1986), Agency Costs of Free Cash Flow, Corporate Finance and Takeovers, American Economic Review, Papers and Proceedings 76, 323-329.

Jensen, M. (1991), Corporate Control and the Politics of Finance, Journal of Applied Corporate Finance 4, 13-33.

Jensen, M. (1993), The Modern Industrial Revolution, Exit, and the Failure of Internal Control Systems, Journal of Finance 48, 831-880.

Kaplan, S. (1994a), Top Executive Rewards and Firm Performance: A Comparison of Japan and the United States, Journal of Political Economy 102, 510-546.

Kaplan, S. (1994b), Top Executives, Turnover, and Firm Performance in Germany, Journal of Law, Economics and Organization 10, 142-159.

La Porta, R., F. Lopez-de-Silanes, A. Shleifer, and R. Vishny (1998), Law and Finance, Journal of Political Economy 106, 1113-1155. 
La Porta, R., F. Lopez-de-Silanes, A. Shleifer, and R. Vishny (1997), Legal Determinants of External Finance, Journal of Finance 52, 1131-1150.

La Porta, R., F. Lopez-de-Silanes, and A. Shleifer (1999), Corporate Ownership Around the World, Journal of Finance 54, 471-517.

La Porta, R., F.Lopez-de-Silanes, A.Shleifer, and R. Vishny (1999), Agency Problems and Dividend Policies Around the World, mimeo, Harvard University, Cambridge, MA.

Landes, D. (1969), The Unbound Prometheus, Cambridge University Press, Cambridge, UK.

Machauer, A., and M.Weber (1998), Bank Behavior Based on Internal Credit Ratings of Borrowers, Journal of Banking and Finance 22, 1355-1383.

Manne, A. (1965), Mergers and the Market for Corporate Control, Journal of Political Economy 73, $110-120$.

Mathias, P. (1969), The First Industrial Nation, Methuen, London.

Mayer, C. (1988), New Issues in Corporate Finance, European Economic Review 32, 1167-1188.

Mayer, C. (1990), Financial Systems, Corporate Finance and Economic Development, in: R.G. Hubbard (ed.), Asymmetric Information, Corporate Finance, and Investment, University of Chicago Press, Chicago, 307-332.

Myers, S. and N.S. Majluf (1984), Corporate Finance and Investment Decisions When Firms Have Information that Investors Do Not Have, Journal of Financial Economics 13, 187-222. 
Noll, P. and H.R. Bachmann (1988), Der kleine Machiavelli, Pendo, Zürich.

Penati, A., and L.Zingales (1998), Efficiency and Distribution in Financial Restructuring: The Case of the Ferruzzi Group, mimeo, University of Chicago, Graduate School of Business, Chicago, IL.

Perlitz, M., and Seger, F. (1994), The Role of Universal Banks in German Corporate Governance, Business and the Contemporary World 6, 49-67.

Pickens, T.B. (1987), Boone, Houghton Mifflin, Boston.

Pohl, H. (1983), Formen und Phasen der Industriefinanzierung bis zum 2. Weltkrieg, Bankhistorisches Archiv 9, 13-33.

Prowse, S. (1994), Corporate Governance in an International Perspective: A Survey of Corporate Control Mechanisms among Large Firms in the United States, the United Kingdom, Japan and Germany, BIS Economic Papers No.41, Bank for International Settlements, Basle.

Rajan, R. and L. Zingales (1998), Financial Dependence and Growth, American Economic Review $88,559-586$.

Riesser, J. (1910), Die Deutschen Grossbanken und ihre Konzentration im Zusammenhang mit der Entwicklung der Gesamtwirtschaft in Deutschland, Gustav Fischer, Jena.

Roe, M.J. (1994), Strong Managers, Weak Owners: The Political Roots of American Corporate Finance, Princeton University Press, Princeton.

Schütz, D. (1998), Der Fall der UBS, Bilanz:Weltwoche-Verlag, Zürich.

Sharpe, S. (1990), Asymmetric Information, Bank Lending, and Implicit Contracts: A Stylized Model of Customer Relationships, Journal of Finance 45, 1069-1087. 
Shleifer, A., and L. Summers (1988), Breach of Trust in Hostile Takeovers, in: A. Auerbach (ed.) Corporate Takeovers, Causes and Consequences, University of Chicago Press, Chicago, 3356 .

Shleifer, A., and R. Vishny (1986), Large Shareholders and Corporate Control, Journal of Political Economy 94, 461-488.

Shleifer, A. and R. Vishny (1997), A Survey of Corporate Governance, Journal of Finance 52, 737783.

Tirole, J. (1998), Corporate Governance, mimeo, Institut d'Economie Industrielle, Toulouse.

Weinstein, D. and Y. Yafeh (1998), On the Costs of a Bank-Centered Financial System: Evidence from the Changing Main Bank Relations in Japan, Journal of Finance 53, 635-672.

Wellhöner, V. (1989), Grossbanken und Grossindustrie im Kaiserreich, Vandenhoek\&Ruprecht, Göttingen.

Wenger, E. (1996), Institutionelle Defizite am deutschen Kapitalmarkt, Report for the German Monopolkommission, Würzburg.

Wixforth, H. (1995), Banken und Schwerindustrie in der Weimarer Republik, Böhlau, Köln.

Ziegler, D. (1998), Die Aufsichtsräte der deutschen Aktiengesellschaften in den zwanziger Jahren: Eine empirische Untersuchung zum Problem der "Bankenmacht", Zeitschrift für Unternehmensgeschichte 43, 194-215. 
Figure 1

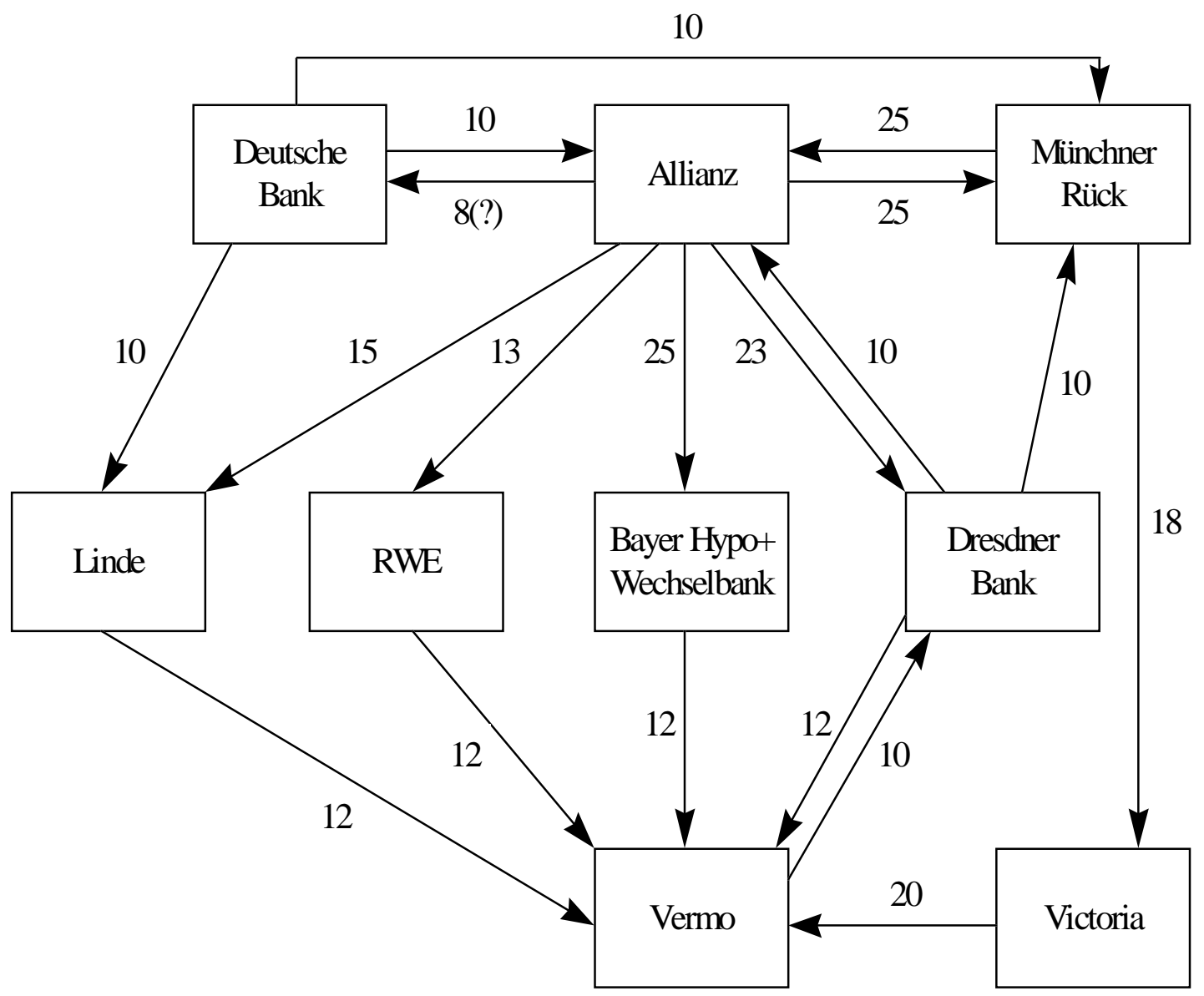




\section{Endnotes}

- Paper presented at the Conference on Corporate Governance of the Institut Català de Finances, Sitges, October 23-24, 1998. I am grateful for comments received from the conference participants,

in particular, the discussants, Andrei Shleifer and Andreu Mas-Colell. Research support from the Schweizerischer Nationalfonds through the University of Basle and from the Deutsche Forschungs-

gemeinschaft is gratefully acknowledged.

1 The observation that the three types of governance structure, those involving large shareholders, those involving banks, and those involving the threat of takeovers, all involve a certain amount of concentration in the provision of finance and the exertion of control is brought out very clearly by Shleifer and Vishny (1997).

2 This 1994 vote at UBS was contested in court on the grounds that as the matter concerned a redistribution of rights between classes of shareholders, there should have been separate votes of the different classes. The matter was still pending when the SBC/UBS merger was announced. Following this merger, the lawsuit was withdrawn for being moot.

3 The reader who is used to teaching MBA students about the social usefulness of the New York Stock Exchange as a source of investment finance may want to puzzle about the following statement from an official of a major Swiss corporation: "We don't regard shares as a source of funds. We have issued shares because we want the public to have a stake in our company. In a direct democracy, with popular votes on on substantive questions, this is important."

4 These considerations raise serious identification problems for empirical research. Apart from the obvious difficulty of distinguishing between large shareholders who are associates of management and large shareholders who are controllers of management, there is the deeper difficulty of 
distinguishing between investor-driven and management-driven correlations in financial data. If $\mathrm{La}$ Porta et al. (1997) observe that, e.g., countries with violations of the rule of one-share-one-vote also

have relatively low stock market capitalizations of equity held by outsiders, does this reflect the market's view that outside equity holders with reduced voting power will be badly treated or does it reflect the neuroses of a management that uses both retentions of large blocks and shares with reduces (or no) voting rights to make sure that it cannot lose control?

5 As a treatment of the "main-bank system", Gerschenkron (1962) adds little to Jeidels (1905) and Riesser (1910), but this was not actually his concern. He was mainly concerned with the conclusion

for development economics "backward economies" can be competitive in the most advanced industries if they have suitable institutions like the German banks collecting funds through deposits or the Russian government collecting funds through taxation in the late nineteenth century.

6 The case studies of Wellhöner (1989) as well as the cliometric studies of Fohlin (1997, 1998a) suggest an extremely heterogeneous picture with bank-firm relations taking all sorts of different forms, including different degrees of dependence and independence.

7 The full extent of cross holdings is not publicly known because they are frequently subdivided so as to remain below the threshold levels that would imply mandatory publication. For a systematic account of publicity requirements annd their insufficiency for ensuring transparency of group structures, see Becht and Böhmer (1997). Using 1985 data at the Bank for International Settlements, Prowse (1994) suggests that $52 \%$ German stock market capitalization is accounted for by cross-holdings, so that after netting the ratio of stock-market capitalization to GNP drops from $29 \%$ to $14 \%$ (the corresponding numbers for the US are $51 \%$ and $48 \%$, for the UK $90 \%$ and $81 \%$ ). Using publicly available 1994 data, Wenger (1996) shows that $27 \%$ of German stock market capitalization is accounted for by known cross-holdings, but he emphasizes that this is a lower bound: Observed inconsistencies between the numbers available in different reporting routes lead him to suggest that the true number must be above $30 \%$ and that Prowse's estimate for 1985 may 
not be too high. In the case of Allianz, publication of the numbers used in Figure 1 has been forced through litigation by Wenger; in fact he had to go through the same litigation for $1991,1992, \ldots$, repeatedly, because in any given year the company again tried to withold the information which it had been told to provide by the court in the year before. Figure 1 gives only holdings exceeding $10 \%$. The full picture, including smaller holdings, exhibits a significantly more intricate maze, see Adams (1994).

8 Anecdotal evidence as told, e.g., by Pickens (1987) suggests that the Fürstenberg attitude to shareholders is not unheard of in American boardrooms as well as German ones.

9 For an exhaustive and systematic account of relevant differences see La Porta et al. (1998).

10 This observation casts doubt upon the use of stock market capitalization as a measure of external share finance in La Porta et al. (1997) or Rajan and Zingales (1998). To be sure, La Porta et al. (1997) try to adjust for insider holdings of shares, but this does not correct for the part of market capitalization that is due to internal growth.

11 This consideration has some relevance for transition policy in Eastern Europe. Given that the situation in Eastern Europe in the nineties has some similarity to that of Germany in the fifties, it may perhaps be less important to settle the "banks versus markets" discussion in Eastern Europe than to provide firms with (i) opportunities to earn profits and (ii) incentives to reinvest these profits at home rather than in Swiss or American bank accounts.

12 One may of course wonder whether the scale economies are not simply in the savings on monitoring effort that comes from one huge as opposed to many small investments. If VW paid DM 1.4 billion for Rolls Royce, did they spend 1000 times the effort they would have spent on a project costing DM 1.4 million? For a formal analysis of the underlying agency problem see Hellwig (1998). 
${ }_{13}$ Historically, partisan expertises have been considered to be part of the university professor's job much earlier than research.

${ }^{14}$ In the Krupp-Thyssen episode, the success of Thyssen's defense was partly due to the fact that through an illegal indiscretion the Krupp offer was prematurely disclosed. As yet the source of the indiscretion has not been established, but some of the evidence seems to point to the state government, represented on board of Krupp and perhaps afraid of a loss in corporate income taxes

in the wake of a highly leveraged takeover.

15 This was the formulation of UBS in its 1994 dispute with a large blockholder.

${ }^{16}$ The impact of bank relations on firm performance is controversial. For Germany, Cable (1985) as well as Gorton and Schmid (1996) argue that "main bank relations" supported by the bank's holding

a significant block of shares have a positive impact on firm profitability. Perlitz and Seger (1994) claim the opposite. Chirinko and Elston (1996) argue that the data do not contain enough information to settle this question. The same applies to the effects of banks' controlling large blocks

of proxy votes. In any case, as pointed out by Edwards and Fischer (1994), a study focussing on banking relations when banks own large blocks of shares will not distinguish between the performance effects of having a large shareholder at all and the effects of having the shareholder be a bank. 